open 2 ACcess

\title{
The Improvement of Experiential Learning Model-Based Management in Public Health Center (Puskesmas) of Indonesia
}

\author{
Andi Mansur Sulolipu ${ }^{1 *}$, Ridwan Amiruddin ${ }^{2}$, Sukri Palutturi ${ }^{3}$, Ridwan M. Thaha ${ }^{4}$, A. A. Arsunan ${ }^{2}$ \\ ${ }^{1}$ Doctoral Program Student, Faculty of Public Health, Universitas Hasanuddin, Makassar, Indonesia; ${ }^{2}$ Department of \\ Epidemiology, Faculty of Public Health, Universitas Hasanuddin, Makassar, Indonesia; ${ }^{3}$ Department of Health Policy and \\ Administration, Faculty of Public Health, Universitas Hasanuddin, Makassar, Indonesia; ${ }^{4}$ Department of Health Education and \\ Behavioral Sciences, Faculty of Public Health, Universitas Hasanuddin, Makassar, Indonesia
}

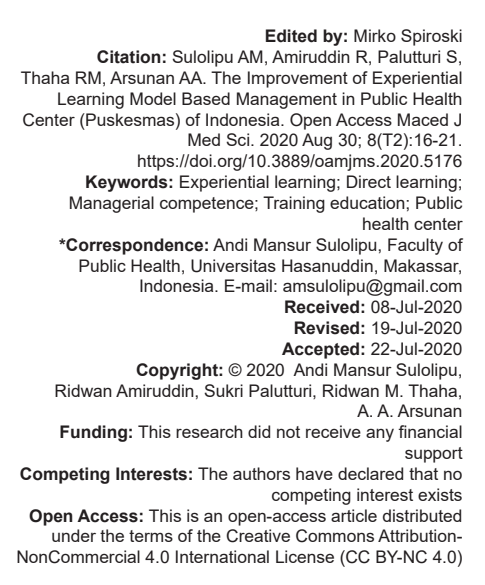

Introduction

As a health-care service facility, public health center provides first degree health service effort for the public and individual by prioritizing promotive and preventive efforts to achieve the highest degree of public health in its working area [1]. It is a functional health organization union in developing the public health in addition to build the role of the community and provides integrated and overall service to the community in its working area in the form of main activities.

A series of process including planning, organizing, actuating, and controlling is called as management to achieve the target or objective effectively and efficiently. Effective means that the objective expected is achieved through well, appropriate, and quality implementation process supported by accurate data and information (evidence based). Meanwhile, efficient means how the public health center can utilize the existing resource to implement the health-care effort according to the standard well and appropriately so that it can actualize the performance target that has been determined [2].

Competence is someone's ability in implementing his duty or work based on his skill and knowledge. Human resource competence development in health aspect is strategic component for health development to accelerate the equal distribution of health service and target achievement of the health development. The quality of human resource is the main element in determining the performance of an organization [3].

Experiential learning strategy facilitates learning well. It has same knowledge perspective in terms of how someone obtains knowledge which is how they learn. Experiential learning is an effective and strong theory to understand and model how people learn in an environment built socially [4]. Experiential learning was measured through indicators based on the stages of concrete experience which is how the training participant involved themselves entirely in the new experience by prioritizing feeling, reflective observation in which the training participant observes and reflects or 
thinks the experience from various aspect by prioritizing watching, abstract conceptualization in which the training participant creates concepts integrating his observation into healthy theory by prioritizing thinking and testing in new situations/experiment, in which the training participant uses theory to solve problems and makes decision by prioritizing doing [4]. Meanwhile, competence is measured by knowledge level, behavior, and skill obtained as the learning result from the training.

Furthermore, this research looked for the contribution of experiential learning strategy on the competency of learning result of the training participant focusing on the experiential learning as the learning model alternative in education and training. This research aimed to test the effectiveness of experiential learning model by improving the health center management competence.

\section{Materials and Methods}

This research employed quasi-experimental through pre-post-test control design by involving 30 heads of public health center and 30 heads of the administration of public health center coming from various public health center in South Sulawesi as the research subject. There were two groups involved in this research; experimental group and control group. The research subjects were not chosen randomly to be involved in experimental group and control group [5].

The experimental group was taught using the experiential learning model (X1), while the control class was taught using direct learning (X2), as described in Table 1. The two-class groups were given pre-test (01 and 03) before taking the learning to measure the equality of the participants' initial ability. After the learning process ended, they were given post-test (02 and 04) to compare their competence before and after the intervention given, and between the experimental and control class. This design was done with treatment and observation schedules according to the stages of experiential learning made in Table 1.

Table 1: Research design of pre-test and post-test

\begin{tabular}{llll}
\hline Subject & Pre-test & Learning implementation & Post-test \\
\hline Group A (experiment) & $0_{1}$ & $\mathrm{X}_{1}$ & $0_{2}$ \\
Group B (control) & $0_{3}$ & $\mathrm{X}_{2}$ & $0_{4}$ \\
\hline
\end{tabular}

\section{Data collection tool}

\section{The question of pre-test and post-test}

The managerial competence of the public health center was measured using pre-test and post-test, both for the experimental and control group. The test question consists of 15 questions of concrete experience, having reliability $\alpha$ Cronbach coefficient of $0.858,15$ questions reflective observation, having reliability $\alpha$
Cronbach coefficient of $0.878,15$ questions abstract conceptualization, having reliability $\alpha$ Cronbach coefficient of 0.888 and 15 questions Testing in New Situations/ experiment, having reliability $\alpha$ Cronbach coefficient of 0.858. Pre-test and post-test covered questions of planning (P1), implementation (P2), and assessment (P3) regarding the management of the Public Health Center.

\section{Working book and Metaplan}

The working book consisted of open questions regarding the planning ( $P 1)$, implementation (P2), and assessment (P3) regarding the management of Public Health Center sourced from the Public Health Center Management Module [6] by considering the subtopic involved in competence test (pre- and post-test). Working book was designed by adopting the practice stages of the implementation of experiential learning in learning, according to Klob (2014).

Metaplan is the assistance tool on the participative training based on card involving the participant to become active to formulate idea and opinion together which was then visualizing it into Metaplan posters (cards were compiled in pieces of Plano papers/ flipchart) so that it showed interesting, solid and structured information. Since the result is in the form of visual, then it will be documented well. This design was validated by three experts; two of them are the professional in training, while another one is an expertise in the education field. The mean score of working book and Metaplan validation result was 82.33 , while the pre-test and post-test was 8.00 or quite valid category to be used.

\section{Data analysis}

The data analysis was tested using an independent sample t-test to determine whether there is a significant score of the competence between the experimental and control groups. A paired sample t-test was used to determine to know whether there was a change of the competence score between the pre-test and post-test in each group. Furthermore, the Pearson correlation coefficient was calculated to determine whether there was a significant correlation of the score obtained from the competence achievement of the post-test with the working paper question result.

\section{Creating an experiential learning scenario}

The experiential learning model is the main object of the Public Health Center Management in which the sub-main discussion are planning (P1), implementation (P2), and assessment (P3) regarding the management of Public Health Center made assisted by Working Book and Metaplan with three stages, in which the first one was the working book fulfillment, the second one was formulating idea or opinion and then visualizing 
it into Metaplan posters together (cards compiled into Plano paper/flipchart), while the third one was discussion concerning the management of the Public Health Center. Those stages led the learning participants to obtain the concept of planning (P1), implementation (P2), and assessment $(\mathrm{P} 3)$ regarding the management of Public Health Center in stages. The learning was conducted for $24 \mathrm{~h}$ of learning (learning hour/JPL) in which each JPL was $45 \mathrm{~min}$, by following the learning schedule made by the training committee (Table 2).

Table 2: Research design of pre-test and post-test

\begin{tabular}{ll}
\hline Implementation & Learning hour \\
\hline EL Stage I Working Book Fulfillment P1 & 3 \\
EL Stage II Metaplan P1 & 2 \\
EL Stage III Discussion P1 & 3 \\
EL Stage I Working Book Fulfillment P2 & 3 \\
EL Stage II Metaplan P2 & 2 \\
EL Stage III Discussion P2 & 3 \\
EL Stage I Working Book Fulfillment P3 & 3 \\
EL Stage II Metaplan P3 & 2 \\
EL Stage III Discussion P3 & 3 \\
\hline
\end{tabular}

In the initial meeting, the facilitator explained the experiential learning and the learning objective as well as grouping the participants into small groups consisting of 4-5 people. Then, the participants entered the main activities which were learning in the group as follow:

EL Stage I of Working Book. Fulfilling the working book through the EL stages of concrete experience, reflective observation, abstract conceptualization, Testing in New Situations/ experiment aiming to find the understanding process model of public health center management easily. In this stage, the participant constructed and understood the management of public health center-based on experiment and main discussion topic of the management of public health center by answering questions in the working book consisting of the discussion sub-topic of planning (P1), implementation (P2), and assessment (P3) regarding the management of Public Health Center.

EL Stage II: Metaplan aimed to produce design of the management of public health center, in which the participants formulated the idea or opinion together which was then visualizing it into Metaplan posters (cards were compiled in pieces of Plano papers/flipchart), based on the experiment and the main topic of public health center management of planning (P1), implementation (P2), and assessment (P3), as the next discussion material.

EL Stage III: Discussion aimed to develop the design of the management of public health center: Planning (P1), implementation (P2), and assessment (P3). In this stage, the participant discussed the concrete experience, reflective observation, abstract conceptualization, and testing in new situations/ experiment. Each participant was given the opportunity to share their different experience with the other participants in the form of Metaplan poster to be shown and explained to all participants. In this stage, the facilitator identified the participants' experiments which were supporting and also those which were encountering difficulties in the learning process.

\section{Results}

\section{Experiential learning and direct learning}

The Effect of experiential learning based on concrete experience, observation and reflection, abstract concepts, dan experiment/ testing new situation on participants' competence

The dependent t-test and Wilcoxon test in Table 3 show that the experiential learning improved the competence of the public health center management training participant with the significance $<0.05$ (sig.<0.05). Based on the following table, the score significant concrete experience $(p=0.00)$, observation and reflective $(p=0.00)$, forming abstract concepts $(p=0.025)$, and testing in new situation $(p=0.003)$ were obtained. Thus, it can be concluded that there was an effect of Experiential learning with $p<0.05$ on the improvement of the competence of public health center management training participants in the training place or temporary system.

Table 3: The effect of experiential learning strategy on the competence of the participants of public health center training

\begin{tabular}{|c|c|c|c|c|}
\hline Experiential learning (intervention) & $\mathrm{n}$ & Mean & Standard deviation & p value \\
\hline \multicolumn{5}{|l|}{ Concrete experience (Planning) } \\
\hline Pre-test score & \multirow[t]{2}{*}{30} & 60.43 & 7.21 & \multirow{2}{*}{$0.000^{*}$} \\
\hline Post-test score & & 82.30 & 9.76 & \\
\hline \multicolumn{5}{|l|}{ Concrete experience (implementation) } \\
\hline Pre-test score & \multirow[t]{2}{*}{30} & 54.00 & 11.62 & \multirow[t]{2}{*}{$0.000^{*}$} \\
\hline Post-test score & & 74.66 & 9.91 & \\
\hline \multicolumn{5}{|l|}{ Concrete experience (assessment) } \\
\hline Pre-test score & \multirow[t]{2}{*}{30} & 52.66 & 12.71 & \multirow[t]{2}{*}{$0.001^{\text {** }}$} \\
\hline Post-test score & & 63.88 & 7.07 & \\
\hline \multicolumn{5}{|l|}{ Concrete experience } \\
\hline Pre-test score & \multirow[t]{2}{*}{30} & 55.70 & 7.21 & \multirow[t]{2}{*}{$0.000^{*}$} \\
\hline Post-test score & & 73.61 & 9.76 & \\
\hline \multicolumn{5}{|l|}{ Observation and reflective (planning) } \\
\hline Pre-test score & \multirow[t]{2}{*}{30} & 61.10 & 7.71 & \multirow[t]{2}{*}{$0.000^{*}$} \\
\hline Post-test Score & & 77.96 & 8.76 & \\
\hline \multicolumn{5}{|c|}{ Observation and reflective (implementation) } \\
\hline Pre-test score & \multirow{2}{*}{30} & 59.00 & 7.70 & \multirow{2}{*}{$0.028^{*}$} \\
\hline Post-test score & & 64.00 & 10.53 & \\
\hline \multicolumn{5}{|c|}{ Observation and reflective (assessment) } \\
\hline Pre-test score & \multirow[t]{2}{*}{30} & 56.33 & 10.05 & \multirow[t]{2}{*}{$0.258^{\star \star}$} \\
\hline Post-test score & & 59.38. & 8.35 & \\
\hline \multicolumn{5}{|l|}{ Observation and reflective } \\
\hline Pre-test score & 30 & 58.81 & 10.74 & $0.000^{*}$ \\
\hline Post-test score & & 67.12 & 9.74 & \\
\hline Forming abstract concepts (plannin & & & & \\
\hline Pre-test score & 30 & 63.90 & 7.21 & $0.001^{*}$ \\
\hline Post-test score & & 76.46 & 9.76 & \\
\hline Forming abstract concepts (implem & & & & \\
\hline Pre-test score & 30 & 58.93 & 13.43 & $0.024^{*}$ \\
\hline Post-test score & & 64.04 & 13.33 & \\
\hline Forming abstract concepts (assess & & & & \\
\hline Pre-test score & 30 & 56.08 & 7.13 & $0.203^{\star \star}$ \\
\hline Post-test score & & 59.45 & 7.13 & \\
\hline Forming abstract concepts & & & & \\
\hline Pre-test score & 30 & 59.63 & 10.74 & $0.025^{*}$ \\
\hline Post-test score & & 66.65 & 9.33 & \\
\hline Testing in new situation (planning) & & & & \\
\hline Pre-test score & 30 & 63.79 & 7.21 & $0.006^{*}$ \\
\hline Post-test score & & 73.96 & 9.76 & \\
\hline Testing in new situation (implement & & & & \\
\hline Pre-test score & 30 & 58.60 & 13.43 & $0.183^{*}$ \\
\hline Post-test score & & 61.70 & 13.33 & \\
\hline Testing in new situation (assessme & & & & \\
\hline Pre-test score & 30 & 57.43 & 7.13 & $0.285^{\star \star}$ \\
\hline Post-test score & & 59.78 & 8.13 & \\
\hline Testing in new situation & & & & \\
\hline Pre-test score & 30 & 59.93 & 10.74 & $0.003^{*}$ \\
\hline Post-test score & & 65.15 & 10.33 & \\
\hline
\end{tabular}

Table 3 indicates that the significance value is $<0.05$ (sig. $<0.05$ ); therefore, it can be concluded that the concrete experience $(p=0.00)$ affected the 
competence of planning (P1), implementation (P2), and assessment $(\mathrm{P} 3)$, the value of observation and reflective $(p=0.00)$ affected the competence of planning (P1), implementation (P2), and assessment (P3), the value of forming abstract concepts $(p=0.025)$ competence of planning (P1), implementation (P2), and assessment $(P 3)$, and the value of testing in new situation $(p=0.003)$ competence of planning (P1), implementation (P2), and assessment (P3).

The effect of experiential learning and direct learning on the competence of planning (P1), implementation (P2), and assessment (P3) on the education and training of the management of public health center in the training center

Based on Table 4, the significance value of the experiential learning strategy using dependent t-test $=0.00$ while the direct learning using the dependent t-test as well as 0.045 . Both of them had $p=0.05$. It means that experiential learning and direct learning improved the competence of the participants of public health center management. Among them, the most influential strategy was experiential learning.

\begin{tabular}{|c|c|c|c|c|}
\hline Learning strategy & $\mathrm{n}$ & Mean & Standard deviation & $p$ value \\
\hline \multicolumn{5}{|l|}{ Intervention } \\
\hline \multicolumn{5}{|c|}{ Experiential learning (planning) } \\
\hline Pretest score & 30 & 60.01 & 7.21 & $0.000^{*}$ \\
\hline Posttest score & & 83.63 & 9.76 & \\
\hline \multicolumn{5}{|c|}{ Experiential learning (implementation) } \\
\hline Pretest Score & 30 & 52.33 & 10.43 & $0.000^{*}$ \\
\hline Posttest score & & 76.33 & 13.33 & \\
\hline \multicolumn{5}{|c|}{ Experiential learning (assessment) } \\
\hline pretest score & 30 & 52.00 & 7.13 & $0.000^{* *}$ \\
\hline Posttest score & & 65.21 & 7.13 & \\
\hline \multicolumn{5}{|c|}{ Experiential learning } \\
\hline Pretest score & 30 & 54.79 & 10.74 & $0.000^{*}$ \\
\hline Posttest score & & 75.06 & 5.82 & \\
\hline \multicolumn{5}{|l|}{ Control } \\
\hline \multicolumn{5}{|c|}{ Direct learning (planning) } \\
\hline Pretest score & 30 & 52.86 & 12.85 & $0.026^{*}$ \\
\hline Posttest score & & 59.15 & 9.71 & \\
\hline \multicolumn{5}{|c|}{ Direct learning (implementation) } \\
\hline Pretest score & 30 & 52.67 & 10.06 & $0.036^{*}$ \\
\hline Posttest score & & 60.18 & 14.86 & \\
\hline \multicolumn{5}{|c|}{ Direct learning (assessment) } \\
\hline Pretest score & 30 & 51.78 & 11.51 & $0.061^{* *}$ \\
\hline Posttest score & & 55.53 & 8.65 & \\
\hline \multicolumn{5}{|l|}{ Direct learning } \\
\hline Pretest score & 30 & 52.44 & 6.84 & $0.045^{*}$ \\
\hline Posttest score & & 61.89 & 9.74 & \\
\hline
\end{tabular}

The difference between experiential learning and direct learning on the competence of planning, implementation, and assessment of the participants of the education and training of public health center management in the training center

Table 5 describes the significance value of the two learning strategies uptake with $p=0.000$ $<0.05$. Thus, it can be summed up that there was different competence uptake between the experiential learning strategy and those who did not implement the experiential learning strategy among the participants of the management of the Public Health Center in the training center. Table 5 also shows that the uptake of assessment (P3) was not distributed normally so that it was continued by non-parametric Mann-Whitney test.

Table 5: The difference of absorbance of experiential learning (intervention) and direct learning (control) uptake

\begin{tabular}{|c|c|c|c|c|c|}
\hline \multicolumn{2}{|l|}{ Learning strategy } & \multirow{2}{*}{$\begin{array}{l}\mathrm{n} \\
30\end{array}$} & \multirow{2}{*}{\begin{tabular}{|l} 
Mean \\
23.61
\end{tabular}} & \multirow{2}{*}{$\begin{array}{l}\begin{array}{l}\text { Standard } \\
\text { deviation }\end{array} \\
19.04\end{array}$} & \multirow{3}{*}{$\begin{array}{l}p \text { value } \\
0,000^{*}\end{array}$} \\
\hline Experiential learning & Planning & & & & \\
\hline Direct Learning & uptake & 30 & 6.28 & 14.63 & \\
\hline $\begin{array}{l}\text { Experiential learning } \\
\text { Direct learning }\end{array}$ & $\begin{array}{l}\text { Implementation } \\
\text { uptake }\end{array}$ & $\begin{array}{l}30 \\
30\end{array}$ & $\begin{array}{l}24.00 \\
7.51\end{array}$ & $\begin{array}{l}9.44 \\
8.69\end{array}$ & $0.001^{*}$ \\
\hline Experiential learning & Assessment & 30 & 13.21 & 8.26 & $0.366^{\star *}$ \\
\hline Direct learning & uptake & 30 & 9.74 & 12.38 & \\
\hline \multicolumn{2}{|c|}{ Experiential learning uptake } & $\begin{array}{l}30 \\
30\end{array}$ & $\begin{array}{l}20,28 \\
7.86\end{array}$ & $\begin{array}{l}13.19 \\
8.95\end{array}$ & $0.000^{*}$ \\
\hline
\end{tabular}

\section{Discussion}

Experiential learning was measured using indicators based on the stages of concrete experience which is how the training participant involved themselves entirely in the new experience by prioritizing feeling, reflective observation in which the training participant observes and reflects or thinks the experience from various aspect by prioritizing watching, abstract conceptualization in which the training participant creates concepts integrating his observation into healthy theory by prioritizing thinking and testing in new situations/experiment in which the training participant uses theory to solve problems, and make decision by prioritizing doing [4].

Experiential learning is holistic and multilinear learning, which emphasized on experience as it has an important role in the learning process. It is also very inviting for the participation and activities of the participant so that it is suitable for adult learning so that the learning process becomes interactive, then it needs tools and material, including cards or colored papers, which can attract the participants' interest called Metaplan paper.

As a facilitation method/technique, Metaplan uses card media to collect, discuss, and develop ideas or opinions as well as agree on various things. Metaplan is first developed by a German named Eberhard. Since a visual media, Metaplan is developed by the participants themselves using various shapes and color of card while the discussion material comes from the experiment and knowledge of all participants, which is then reviewed and made as an experiential learning strategy.

Experiential learning or known as learning through creating an experience is one of the strategies in education and training, where the training participants share their experience as a knowledge source after the learning process in the Public Health Center Management learning process ends.

Direct learning is supported by behavior and cognitive social theories Arends [7]. The learning 
behavior theories have been contributing a lot and significantly on the direct learning, especially from Skinner who stated that human learns and behaves in a certain way as the result of certain behavior strengthening. Facilitator which teaches according to the behavior principal designs the target and explains what will be learned by the participants, shares learning experiences, such as exercise, discussion and question, and answer so that the participant can give feedback and gives special attention on how to facilitates the participants' behavior in accepting the material in class.

An experiential learning strategy is a learningteaching process model that activated the learner to build knowledge and skill through direct experience. An experiential learning strategy is a learning model which pays attention to the experiences owned by the training participants. The participant of the training directly involved in the learning process and they are from various health professions constructing their own experience obtained either in the training center or in their public health center. Therefore, it can become the knowledge source in implementing the management of a public health center and knowledge management.

This is in accordance with Amalia [8] who stated that experiential learning is the process of making meaning from direct experience. Based on the definition, experiential learning is a process of making meaning, understanding, or through direct experience. The learning strategy covers the material organizing strategy, material delivery strategy, which reviews the learning media and the organizing media, including learning strategy organization and learning media management strategy [9]. Effective, efficient, and interesting learning strategy to achieve suitable learning results for certain learning conditions is really needed to achieve the learning result [10].

Training is a systematic approach to increase the effectiveness of individual, team, and organization through the improvement of knowledge, skill, and behavior [11]. Training is defined as systematic effort in modifying and developing knowledge, and behavior needed in learning from the experience for specific performance often neglected [12].

\section{Conclusion}

This research review focused on experiential learning as a learning model alternative in education and training of health workers. This research was conducted on the training of public health center management participated by health workers. The participants came from various public health centers in South Sulawesi. The research result indicates that the use of the experiential learning model is for teaching the management of public health centers to become more effective in improving the competence of planning, implementation, and assessment compared to direct learning that has been used to date. The experiential learning model indicates a better learning result and produces health worker training, which is in accordance with the needs. The learning through experiential learning also looks more challenging since the learning starts from the experience in the working place (Public Health Center) and also the interactive between participant and facilitator using learning media of working book and Metaplan.

The experiential learning model focuses on the participants' experience integrated with the theory based on Public Health Center management module so that the participants were not only learning the reality in various public health center but also the scientific method based on the literature disciplines in the form of module. The application of experiential learning in education and training can encourage the participants to become interactive and learn based on their own experience in the temporary system (training center). This experience is really needed to implement the public health center management and encourage the participants to carry out knowledge management di public health centers (permanent system).

Experiential learning can be chosen as learning model in education and training, which pays attention to the learning environmental factors, including time adequacy, learning media needs, and other supports such as internet access. Such supports are needed to maximize the potential and experience owned by the participant and give an opportunity to the participant to develop their competence in the field of public health center management.

The policy makers who start to pay attention to online education and training for the health worker by considering to integrate experiential learning in it as education and training model which is in accordance with the participants needs and training according to each public health center.

\section{References}

1. Kementerian Kesehatan RI, Peraturan Menteri Kesehatan No. 75. Tentang Puskesmas; 2014. https://doi.org/10.33490/jkm. v4i2.99

2. Kementerian Kesehatan RI, Peraturan Menteri Kesehatan No. 44. Tentang Manajemen Puskesmas; 2014.

3. Parker CL, Barnett DJ, Fews AL, Blodgett D, Links JM. The road map to preparedness: A competency-based approach to all-hazards emergency readiness training for the public health workforce. Public Health Rep. 2005;120(5):504-14. https://doi. org/10.1177/003335490512000505 PMid:16224983

4. Kolb DA. Experiential Learning: Experience as The Source of Learning and Development. United States: FT Press; 2014. 
5. Setyosari HP. Metode Penelitian Pendidikan and Pengembangan. United States: Prenada Media; 2016.

6. Kementerian Kesehatan RI, Modul Manajemen Puskesma Tentang; 2017.

7. Arends RI. Learning to Teach. $9^{\text {th }}$ ed. New York: McGrw-Hill; 2008.

8. Amalia R. Model experiential learning dalam pembelajaran menulis teks narasi. J Bahasa Sastra Pembelajaran. 2017;3(1):112. https://doi.org/10.21776/ub.hastawiyata.2018.001.01.05

9. Nyoman SD. IImu Pembelajaran: Klasifikasi Variabel Untuk Pengembangan Teori dan Penelitian. Bandung: Aras Media;
2013.

10. Reigeluth CM, Cheliman CA. Theories for different outcomes of instruction. Reigeluth CM, Carr-Cheliman AA, editors. Instructional-design Theories and Models: Building a Common Knowledge Base. Vol. 3. New York: Routledge; 2009. p. 195-7. https://doi.org/10.4324/9780203872130

11. Aguinis $\mathrm{H}$, Kraiger $\mathrm{K}$. Benefits of training and development for individuals and teams, organizations, and society. Annu Rev Psychol. 2009;60(1):451-74. https://doi.org/10.1146/annurev. psych.60.110707.163505

12. Buckley R, Caple J. The Theory and Practice of Training. $6^{\text {th }}$ ed. London: Kogan Page; 2009. 